\title{
Broiler breeders utilise body lipid as an energy source
}

\author{
M.K. Nonis \& R.M. Gous ${ }^{\#}$ \\ Animal and Poultry Science, School of Agricultural, Earth and Environmental Sciences, \\ University of KwaZulu-Natal, Private Bag X01, Scottsville 3209, South Africa
}

Copyright resides with the authors in terms of the Creative Commons Attribution 2.5 South African Licence.

See: http://creativecommons.org/licenses/by/2.5/za

Condition of use: The user may copy, distribute, transmit and adapt the work, but must recognise the authors and the South African Journal of Animal Science.

\begin{abstract}
The study was conducted to determine the extent to which broiler breeder hens could make use of excess body lipid reserves as a means of maintaining laying performance. The experiment was divided into two phases. In the first phase, the birds aged 37 weeks were allocated one of four daily allowances: 160, 175, 190 or $205 \mathrm{~g}$ of a commercial broiler breeder feed for a period of four weeks in order to achieve four levels of fatness in the hens. During the second phase, also lasting four weeks, the birds were given a high protein, low energy feed at three rates of allocation $(120,100$ or $80 \mathrm{~g} /$ hen d). Performance was higher over the final two weeks of Phase 2 when birds were fed $120 \mathrm{~g} / \mathrm{d}$ in this period, with production tending to decrease as allocations increased in Phase 1, although this was not significant. The same pattern of response was seen in birds given $100 \mathrm{~g} / \mathrm{d}$ in the second phase of the trial, i.e. excessive lipid reserves tended to be detrimental to performance in these two treatments. However, where $80 \mathrm{~g}$ was allocated daily in Phase 2 this was clearly insufficient to sustain performance, but in this case egg production was considerably higher in birds that had been given larger amounts of food in Phase 1, and which could therefore draw on body lipid reserves as a source of energy. Rate of lay increased by $3.5 \%$ and egg output by $4.0 \mathrm{~g} / \mathrm{d}$ for every additional $10 \mathrm{~g}$ of food given in Phase 1, as a result of lipid reserves having been utilised when daily food intake was severely depressed. Egg weight was not affected by any of the feed allocations until the last two weeks of the trial when birds fed $80 \mathrm{~g} / \mathrm{d}$ started laying smaller eggs. Broiler breeders are capable of maintaining their egg production for short periods at an energy intake that is much lower than is recommended and this has implications when modelling the effect of food composition on performance of broiler breeder hens.
\end{abstract}

Keywords: Lipid reserves, breeders, laying period

\#Corresponding author: gous@ukzn.ac.za

\section{Introduction}

Regulation of food intake of broiler breeders during the laying period is an effective means of reducing costs and improving the efficiency of broiler chick production. Food allowances for breeder hens are manipulated according to the pattern of egg production. Thus, birds are generally fed a generous allowance early in lay followed by a period of mild regulation over peak production and a subsequent reduction in allowance as egg production declines in the latter part of lay. It is accepted that if broiler breeders are overfed they deposit the excess energy as carcass fat and this may lead to a marked reduction in egg production, fertility and hatchability (McDaniel et al., 1981; Pearson \& Herron, 1981). However, it has been shown that fattened broilers utilise lipid reserves as an energy source provided the dietary protein intake is sufficient to allow this (Gous et al., 1992; 2012). Thus, contrary to the way in which amino acid requirements are calculated, when calculating the energy required by a broiler for maintenance and growth, account should be taken of the possibility that excess energy may be stored and later utilised by the bird. The same would apply to broiler breeders. If broiler breeder hens are able to draw on lipid reserves to supply the body with energy, it is less likely that energy will be the limiting factor in egg production, unless food intake is severely restricted, as lipid reserves would be built up on non-egg forming days, to be available when required. However, if the lipid stores are not labile reserves of energy, or if the hen cannot utilise these 
stores, no assumptions could be made about the adequacy of dietary energy supply by observing the carcass fat content of broiler breeders. In the unlikely event that broiler breeder hens were incapable of making full use of lipid reserves, there would be no advantage in allowing the accumulation of such reserves, and the way in which the energy requirements are calculated would become more complex and critical.

The present study was designed to determine the extent to which broiler breeder hens could make use of excess body lipid reserves as a means of maintaining laying performance.

\section{Materials and Methods}

Three hundred and fifty two Cobb broiler breeder hens aged 37 weeks were used in the trial. The birds had been reared on two different growth curves, the first as recommended by the primary breeder (Cobb 500 breeding guide, 2001) designed to achieve $2100 \mathrm{~g}$ at 20 weeks, while the other was a fast growth curve to achieve the same weight, but at 15 weeks. One hundred and seventy six birds from each growth curve were randomly allocated to individual cages arranged in six rows, back to back, each row having two levels of 48 cages. Each cage was supplied with one nipple drinker and drip cup, and one feeder. The house was crossventilated using six fans. The lighting programme was 16L : 8D (04:00 - 20:00) throughout the experimental period.

The experiment was divided into two phases. In the first phase, the birds were allocated one of four daily allowances: 160, 175, 190 or $205 \mathrm{~g}$ of a commercial broiler breeder feed (11.9 MJ ME, $159 \mathrm{~g}$ protein and $24 \mathrm{~g}$ calcium $/ \mathrm{kg}$ ) for a period of four weeks in order to achieve four levels of fatness in the hens. During the second phase, also lasting four weeks, the birds were given a high protein, low energy feed (Table 1) at three rates of allocation $(120,100$ or $80 \mathrm{~g} / \mathrm{hen} \mathrm{d})$. During this second phase a feed with a high dietary protein content was used to ensure that the amino acid supply was adequate at the low food intakes applied, i.e. such that dietary energy was likely to be limiting and not other essential nutrients. In the second phase of the trial the 24 treatments ( 2 initial growth curves, 4 initial levels of fatness, 3 final feed allocations) were replicated using 14 hens per treatment (Table 2). The basal diet was analysed for AME, protein, digestible amino acids, calcium and phosphorus content. AME was measured using the method of McNab \& Blair (1988) in which $50 \mathrm{~g}$ of the feed is given by tube (Sibbald, 1976) following a $48 \mathrm{~h}$ fasting period, and excreta are collected

Table 1 Ingredient and nutrient (determined) composition $(\mathrm{g} / \mathrm{kg})$ of the feed used in Phase 2 of the trial. Digestible amino acid contents are given

\begin{tabular}{lc}
\hline Ingredient & Basal feed \\
\hline Maize & 472 \\
Soybean 48 & 318 \\
Sunflower 37 & 31.3 \\
Wheat bran & 86.5 \\
DL methionine & 1.7 \\
Vit + min premix & 1.5 \\
Limestone & 76.1 \\
Salt & 4.5 \\
Monocalcium phosphate & 8.8 \\
\hline Nutrient & \\
AME (MJ/kg) & 10.1 \\
Crude protein & 211 \\
Lysine & 9.5 \\
Methionine & - \\
Threonine & 5.1 \\
Arginine & 8.4 \\
Calcium & 36.9 \\
\hline
\end{tabular}


over the following $48 \mathrm{~h}$. The AME value was corrected to zero $\mathrm{N}$ retention and to reflect an intake of $80 \mathrm{~g} / \mathrm{d}$ $\left(\mathrm{AME}_{n 80}\right)$. Protein was measured as nitrogen x 6.25 using a LECO N analyser; amino acids by the method described by Dennison \& Gous (1980); and calcium and phosphorus using the AOAC (1975) methods of analysis.

Bodyweight was recorded at the beginning of the trial, after four weeks and then weekly until the end of the trial (after eight weeks). Food intake was calculated by subtracting the amount remaining at the end of each week from the amount fed. Egg production was recorded daily, and egg weight on three days of each week. At the end of the first phase of the experiment, two birds from each daily allowance and from each growth curve (a total of 16 birds) were sacrificed and their carcasses, excluding feathers were minced and then analysed for gross energy (GE), protein, moisture and ash. The lipid content (LC) of the feather-free body was calculated from the GE content using the following equation (University of KwaZulu-Natal, unpublished) which was based on the feather-free analyses of 36 broiler and 24 broiler breeder carcasses and having an $\mathrm{R}^{2}$ value of 0.929 : $\mathrm{LC}=-0.8756( \pm 0.0763)+0.04754( \pm 0.003) *$ GE. Fourteen birds thus remained on each of the 24 treatments. Two of these birds from each treatment were sacrificed at week 5 , another two at week 6 and a further three at the end of the trial. The abdominal fat pad was removed from each bird and weighed and 10 of these birds were chosen for carcass analysis on the basis of the distribution of the weights of their abdominal fat pads. All results were converted to concentrations on a wet basis.

Table 2 A description of the dietary treatments used in the trial

\begin{tabular}{ccccc}
\hline Treatment* & \multicolumn{2}{c}{ Food allocation } & $\begin{array}{c}\text { Lysine intake } \\
\text { Phase 2 } \\
\text { (mg/d) }\end{array}$ & $\begin{array}{c}\text { Energy intake } \\
\text { Phase 2 } \\
\text { (kJ AME/d) }\end{array}$ \\
\hline & Phase 1 & $\begin{array}{c}\text { Phase 2 } \\
\text { (g/bird d) }\end{array}$ & 760 & 805 \\
1 & 160 & 80 & 950 & 1006 \\
2 & 160 & 100 & 1140 & 1208 \\
3 & 160 & 120 & 760 & 805 \\
4 & 175 & 80 & 950 & 1006 \\
5 & 175 & 100 & 1140 & 1208 \\
6 & 175 & 120 & 760 & 805 \\
7 & 190 & 80 & 950 & 1006 \\
8 & 190 & 100 & 1140 & 1208 \\
9 & 190 & 120 & 760 & 805 \\
10 & 205 & 80 & 950 & 1006 \\
11 & 205 & 100 & 1140 & 1208 \\
12 & 205 & 120 & &
\end{tabular}

* The 12 treatments shown were allocated to birds from two initial growth curves resulting in 24 treatments.

The mean response over the final two weeks of Phase 2 was used to calculate rate of lay, egg weight, egg output, body weight and change in body weight, using the general analysis of variance in Genstat (1997). The changes in body weight, rate of lay, egg weight and egg output over time were analysed by fitting a linear regression model to the data, using Genstat. A quadratic term was fitted initially in all cases, and where this was not significant only the linear term was used to describe the response. For the 16 birds that were sacrificed at the end of the first phase of the trial, a regression of carcass fat on body weight was performed. Mean body lipid content ( $\mathrm{g} / \mathrm{kg}$ body weight) for each treatment was calculated and used to predict the body lipid contents of all the remaining birds on each treatment at the end of the first phase. A regression analysis was performed of carcass fat content $(\mathrm{g} / \mathrm{kg}$ bodyweight), calculated from GE, on abdominal fat content ( $\mathrm{g} / \mathrm{kg}$ bodyweight) for the 10 birds sacrificed at weeks 5,6 and 8 . The resultant regression equations were used to predict the carcass lipid contents from the abdominal fat contents of the remaining 288 birds at week 5, 240 birds at week 6 and 168 birds at week 8 . The mean body lipid content for 
each treatment was then used to calculate the body lipid content of all the remaining birds over the four-week period of Phase 2. An analysis of variance was then performed on these body lipid contents.

This trial was conducted in 2004, prior to ethical approval being required by the University of KwaZulu-Natal for such projects, but subsequent trials of this nature have been approved by their Animal Ethics committee.

\section{Results}

The individual results were grouped according to treatment. Three birds, which stopped laying during the trial and looked sick, were excluded from the analysis. Apart from the body water and body lipid contents of birds reared on the two growth curves, no differences were observed across treatments or within phases in any of the other variates measured, hence these data were pooled to increase the number of replications per dietary treatment. The effect of feeding four daily allowances $(160,175,190$ and $205 \mathrm{~g} / \mathrm{bird}$ d) on body weight at the end of the four weeks and laying performance (rate of laying, egg weight and egg output) in the last week of Phase 1 of the trial is shown in Table 3. There were no significant differences in rate of lay, egg weight or egg output between birds fed these allocations during Phase 1. However, body weights at the end of the period were different. As was intended, the heaviest birds were those fed the highest daily feed allocation at the end of the first phase of the trial. During the four-week period the mean gain in weight of birds on each treatment, corrected for initial body weight, was 234, 346, 406 and $527 \mathrm{~g}$.

The chemical composition of the hens sampled at the end of Phase 1 is shown in Table 4. Both body water and body lipid content differed $(P<0.05)$ between birds reared on the two growth curves, with the water content being lower and lipid content being higher in birds reared on the faster growth curve. However, there were no differences in carcass composition between birds on the four initial feeding treatments at the end of the first phase. There was also no relationship between carcass fat content and body weight in these 16 birds.

The mean responses in laying performance, body weight and gain in weight to the daily feed allowances in Phases 1 and 2 over the final two weeks of the trial are presented in Table 5, and the rates of change in rate of lay, egg output and change in body weight over the last four weeks (Phase 2) are presented in Table 6. Body weight of the breeders increased $(P<0.05)$ with feed allocation in both periods. However, body weight loss during the final four weeks of the trial was inversely related to the weight of the birds at the end of Phase 1 (the heaviest birds at the start of Phase 2 lost the greatest amount of body weight), but decreased with increasing feed allocation in Phase 2. There was a significant interaction between the amounts of feed allocated in the two periods during the last two weeks of the trial: the body weight of birds fed 100 and 120 g/d in Phase 2, following 160, 175 and 190 g/d in Phase 1, decreased linearly over time. On 160 and $175 \mathrm{~g} / \mathrm{d}$ in Phase 1, the difference in body weight between birds fed 100 and $120 \mathrm{~g} / \mathrm{d}$ in Phase 2 decreased over time and the mean body weight over the final two weeks was not significantly different. Birds fed $190 \mathrm{~g} / \mathrm{d}$ in Phase 1 and $100 \mathrm{~g} / \mathrm{d}$ in Phase 2 had body weights that decreased more rapidly (-281 vs. $-141 \mathrm{~g} /$ week) and were lighter (3468 vs. $3715 \mathrm{~g}$ ) over the last two weeks than birds fed $120 \mathrm{~g} / \mathrm{d}$. The mean body weight over the final two weeks was the same between birds fed $100 \mathrm{~g} / \mathrm{d}$ in Phase 2 and 160, 175 and $190 \mathrm{~g} / \mathrm{d}$ in Phase 1 . Birds fed $120 \mathrm{~g} / \mathrm{d}$ in Phase 2 and $190 \mathrm{~g} / \mathrm{d}$ in Phase 1 were significantly heavier than those

Table 3 Mean body weight and laying performance of broiler breeders in the last week of Phase 1

\begin{tabular}{lcccc}
\hline & \multicolumn{4}{c}{ Food allocation, g/bird d } \\
\cline { 2 - 5 } & 160 & 175 & 190 & 205 \\
\hline Body weight, g & $3770 \pm 29 *$ & $3884 \pm 26$ & $3946 \pm 29$ & $4046 \pm 27$ \\
Rate of lay, eggs/100 bird d & $69.0 \pm 2.0$ & $69.8 \pm 2.3$ & $70.6 \pm 2.2$ & $68.3 \pm 2.2$ \\
Egg weight, g & $70.1 \pm 0.5$ & $69.0 \pm 0.6$ & $70.0 \pm 0.5$ & $69.5 \pm 0.5$ \\
Egg output, g/bird d & $49.4 \pm 1.4$ & $50.7 \pm 1.4$ & $52.4 \pm 1.2$ & $49.4 \pm 1.4$ \\
\hline
\end{tabular}

\footnotetext{
* Standard error.
} 
Table 4 Mean carcass composition $(\mathrm{g} / \mathrm{kg})$ of the broiler breeders reared on the control $(\mathrm{C})$ and fast $(\mathrm{F})$ growth curves at the end of Phase 1

\begin{tabular}{|c|c|c|c|c|c|c|}
\hline \multirow{2}{*}{$\begin{array}{c}\text { Food } \\
\text { allocation } \\
\text { g/bird d }\end{array}$} & \multicolumn{2}{|c|}{ Water } & \multirow{2}{*}{ Protein } & \multicolumn{2}{|c|}{ Lipid* } & \multirow{2}{*}{ Ash } \\
\hline & Control & Fast & & Control & Fast & \\
\hline 160 & 661 & 636 & 151 & 135 & 167 & 23.3 \\
\hline 175 & 631 & 611 & 186 & 179 & 193 & 21.0 \\
\hline 190 & 645 & 620 & 169 & 145 & 193 & 23.6 \\
\hline 205 & 662 & 612 & 168 & 143 & 192 & 20.3 \\
\hline SEM $^{1}$ & \multicolumn{2}{|c|}{17.7} & 21.7 & \multicolumn{2}{|c|}{20.7} & 3.33 \\
\hline
\end{tabular}

SEM: standard error of mean.

* Predicted from gross energy of carcass using equation given in text.

fed 120 g/d in Phase 2 and either 160 or 175 g/d in Phase 1 (3715 vs. 3463 vs. 3499 g, respectively). Body weight decreased quadratically with age (rapidly at first, and slowing down thereafter) in all birds fed $80 \mathrm{~g} / \mathrm{d}$ and in those fed either 100 or $120 \mathrm{~g} / \mathrm{d}$ in Phase 2 following $205 \mathrm{~g} / \mathrm{d}$ in Phase 1.

Table 5 Responses of broiler breeders to feed allowances in Phases 1 and 2, over the last two weeks of Phase 2, in rate of lay (ROL), egg weight (EW), egg output (EO), body weight (BW) and daily change in body weight $(\mathrm{dW})$

\begin{tabular}{rrrrrrr}
\hline \multicolumn{2}{c}{ Food allocation (g/d) } & ROL $(\%)$ & EW $(\mathrm{g})$ & EO $(\mathrm{g} / \mathrm{d})$ & BW $(\mathrm{g})$ & $\mathrm{dW}(\mathrm{g} / \mathrm{d})$ \\
Phase 1 & Phase 2 & & & & & \\
\hline 160 & 80 & 39.6 & 68.6 & 19.6 & 3281 & -9.3 \\
160 & 100 & 58.9 & 69.7 & 41.0 & 3470 & -11.5 \\
160 & 120 & 69.6 & 69.5 & 48.2 & 3463 & -4.0 \\
175 & 80 & 33.4 & 67.8 & 21.9 & 3368 & -8.6 \\
175 & 100 & 55.4 & 70.2 & 39.0 & 3411 & -11.2 \\
175 & 120 & 64.3 & 68.2 & 45.8 & 3499 & -6.6 \\
190 & 80 & 41.2 & 68.0 & 27.8 & 3343 & -11.8 \\
190 & 100 & 61.3 & 69.9 & 42.8 & 3468 & -14.6 \\
190 & 120 & 63.7 & 70.7 & 47.0 & 3715 & -6.7 \\
205 & 80 & 49.4 & 68.4 & 37.1 & 3452 & -14.6 \\
205 & 100 & 51.2 & 68.5 & 36.2 & 3461 & -9.4 \\
205 & 120 & 66.1 & 69.4 & 45.9 & 3780 & -6.0 \\
\hline
\end{tabular}

There were no significant differences in rate of lay or egg output at the end of the first phase of the trial, i.e. hens on food intakes ranging from 160 to $205 \mathrm{~g} / \mathrm{d}$ had the same egg output. However, the amount of food allocated during Phase 1 significantly influenced both rate of lay and egg output of some birds in Phase 2. In hens fed only $80 \mathrm{~g} / \mathrm{d}$ in Phase 2 , rate of lay and egg output increased at a rate of $3.5 \%$ and $4.0 \mathrm{~g} / \mathrm{d}$, respectively, for every additional $10 \mathrm{~g}$ of food given in period 1 . However, these variables remained the same over the last two weeks when birds were fed either 100 or $120 \mathrm{~g} / \mathrm{d}$, irrespective of the amount fed in Phase 1. The result is presented graphically in Figure 1 . Rate of lay and egg output both increased $(P<0.05)$ with increasing feed allocation in Phase 2. There was also a linear decline $(P<0.001)$ in rate of lay and egg output over time. Mean rate of lay and egg output over the last two weeks of Phase 2, of all hens fed $80 \mathrm{~g} / \mathrm{d}$ in Phase 
2 other than those fed $205 \mathrm{~g} / \mathrm{d}$ in Phase 1 , were lower $(P<0.001)$, and declined more rapidly, than those fed $100 \mathrm{~g} / \mathrm{d}$ in Phase 2. Where hens were fed $120 \mathrm{~g} / \mathrm{d}$ in Phase 2, rate of lay and egg output remained the same throughout the four-week period.

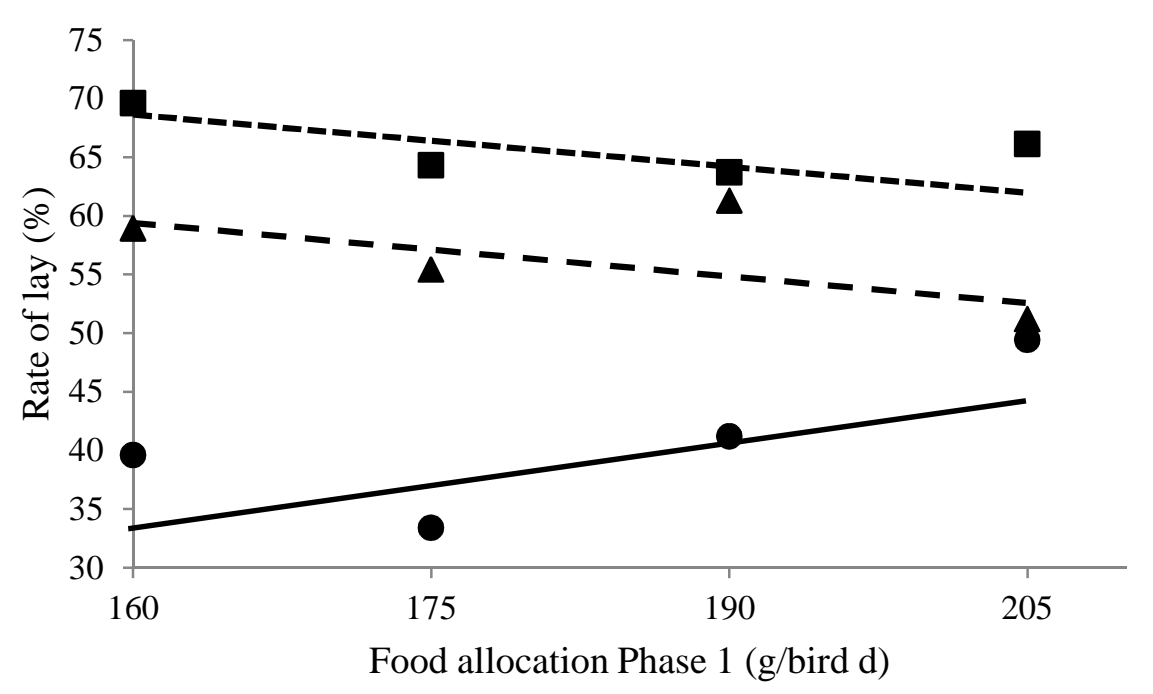

Figure 1 Rate of lay of broiler breeder hens over the final two-week period of the trial according to their daily feed allowances in Phases 1 and 2. Solid line and $\bullet$ represent $80 \mathrm{~g} / \mathrm{d}$ in Phase 2, dashed line and represent $100 \mathrm{~g} / \mathrm{d}$, and dotted line and $\mathbf{m}$ represent $120 \mathrm{~g} / \mathrm{d}$.

The mean abdominal fat and carcass lipid contents of the 10 birds sampled from each treatment 5,6 and 8 weeks after the start of the trial are presented in Table 8 together with their standard errors. The relationship between these components was found to be highly significant $(P<0.001)$ (Table 7$)$ at each sampling time, with the regression coefficients for weeks 43 and 45 being the same $(4.887 \pm 0.619)$. These regressions were used to estimate the carcass lipid contents of the remaining birds sampled where only the abdominal fat contents were measured. No effect of dietary treatment on abdominal fat or carcass lipid content was discernible at week 5 . However, by weeks 6 and 8 abdominal fat pad and carcass lipid contents increased with feed allocation in Phase 2. The rate of change in body lipid content over time for each of the treatments applied is presented in Table 9. The mean abdominal fat pad and body lipid contents of birds fed $80 \mathrm{~g} / \mathrm{d}$ in Phase 2 decreased most rapidly, followed by those fed 100 and then $120 \mathrm{~g} / \mathrm{d}$ on the treatments in which 160, 175 and $190 \mathrm{~g}$ was allocated/d in Phase 1. Birds fed $205 \mathrm{~g} / \mathrm{d}$ in Phase 1 showed a same rate of decline in abdominal fat and body lipid content on all treatments in Phase 2.

\section{Discussion}

Meeting the energy requirement of broiler breeder hens throughout their various stages of production is difficult because their food intake is restricted. The problem of overfeeding broiler breeders is a real concern to any broiler breeder manager, because it leads to the deposition of body lipid which has a negative effect on reproductive performance (McDaniel et al, 1981; Pearson \& Herron, 1981). Underfeeding these birds is also of concern, especially with day-to-day fluctuations in temperature. If broiler breeder hens were found to utilise their body lipid reserves as an energy source, it would certainly assist in alleviating these difficulties. It appears from the results of this trial that they are capable of doing so.

The intention of allocating a range of feed intakes to the breeder hens during Phase 1 of the trial was to create four groups of birds with varying levels of body lipid. However, whereas body weight at the end of this period was directly related to food allocation and to energy intake, there was no relationship between body weight and carcass fat content among the birds sampled. We have shown (Nonis \& Gous, unpublished) that broiler breeder hens do not deposit body protein once they have started laying, and that the changes that occur in body weight after sexual maturity are a reflection of changes in body lipid content. This in turn is a 
response to changes in dietary energy supply and that required for maintenance and egg output. Because of the large variation in weight and carcass composition between birds it is possible that the sample size was too small to make meaningful deductions about the relationship between body weight and lipid content. Because weight gain of breeders during lay has been reported to be primarily related to excessive energy intake (Pearson \& Herron, 1980; 1982; Wilson \& Harms, 1986) it is likely that the lipid reserves in the heaviest birds were greater than in the lighter birds at the end of Phase 1 . This is borne out by the subsequent laying performance of hens in the second phase, which essentially followed expectations based on feed allocations in Phases 1 and 2.

Table 6 Rate of change in performance (rate of lay and egg output) and in body weight over the last four weeks of the trial as influenced by the feed allocated in Phase 1 and Phase 2

\begin{tabular}{|c|c|c|c|c|c|}
\hline \multicolumn{2}{|c|}{ Food allocation $(\mathrm{g} / \mathrm{d})$} & \multicolumn{2}{|c|}{ Rate of lay $(\% / d)$} & \multicolumn{2}{|c|}{ Egg output (g/bird d /d) } \\
\hline Phase 1 & Phase 2 & Linear coefficient & $\mathrm{SE}$ & Linear coefficient & SE \\
\hline 160 & 80 & $-1.5^{* * *}$ & 1.4 & $-1.3^{* * *}$ & 0.2 \\
\hline 160 & 100 & $-0.5^{* * *}$ & 1.1 & $-0.3^{* *}$ & 0.1 \\
\hline 160 & 120 & 0.2 & & 0.1 & \\
\hline 175 & 80 & $-1.5 * * *$ & 1.7 & $-1.1 * * *$ & 0.2 \\
\hline 175 & 100 & $-0.7 * * *$ & 1.3 & $-0.5^{* * *}$ & 0.1 \\
\hline 175 & 120 & $-0.4 *$ & 1.4 & -0.2 & \\
\hline 190 & 80 & $-1.4 * * *$ & 1.3 & $-1.0^{* * * *}$ & 0.1 \\
\hline 190 & 100 & $-0.5^{* *}$ & 1.2 & $-0.4 * * *$ & 0.1 \\
\hline 190 & 120 & -0.1 & & -0.1 & \\
\hline 205 & 80 & $-1.0 * * *$ & 1.5 & $-0.6 * *$ & 0.1 \\
\hline 205 & 100 & $-0.9 * * *$ & 1.4 & $-0.6^{* * *}$ & 0.1 \\
\hline 205 & 120 & 0.2 & & 0.01 & \\
\hline \multicolumn{2}{|c|}{ Food allocation (g/d) } & \multicolumn{4}{|c|}{ Body weight loss (g/bird d) } \\
\hline Phase 1 & Phase 2 & Linear coefficient & SE & Quadratic effect & SE \\
\hline 160 & 80 & $-34.7 * * *$ & 7.1 & $0.584 *$ & 0.259 \\
\hline 160 & 100 & $-14.8^{* * * *}$ & 3.26 & & \\
\hline 160 & 120 & $-8.4^{* * *}$ & 2.4 & & \\
\hline 175 & 80 & $-40.0^{* * * *}$ & 7.9 & $0.741 *$ & 0.286 \\
\hline 175 & 100 & $-17.1^{* * * *}$ & 2.2 & & \\
\hline 175 & 120 & $-15.5^{* * * *}$ & 2.5 & & \\
\hline 190 & 80 & $-40.1 * * *$ & 8.5 & $0.700 *$ & 0.306 \\
\hline 190 & 100 & $-20.1 * * *$ & 2.3 & & \\
\hline 190 & 120 & $-10.3^{* * *}$ & 3.4 & & \\
\hline 205 & 80 & $-44.9 * * *$ & 10.0 & $0.863 *$ & 0.363 \\
\hline 205 & 100 & $-41.8^{* * * *}$ & 7.8 & $0.710 *$ & 0.282 \\
\hline 205 & 120 & $-35.1 * * *$ & 7.1 & $0.918^{* * * *}$ & 0.259 \\
\hline
\end{tabular}

*** $P<0.001 ; * * P<0.01 ; * P<0.05$.

SE: standard error.

The method used to calculate body lipid content from the GE content of the body is based on a substantial dataset collected in our laboratory. Apart from being highly positively correlated with actual body lipid, the lipid content derived in this way has been shown to be highly negatively correlated with body water content. This is another variable that could have been used to predict lipid content without incurring the expense and time involved in determining the lipid content of the body using a Soxhlett apparatus. But both 
Table 7 Main effects of abdominal fat pad and body lipid contents ( $\mathrm{g} / \mathrm{kg}$ body weight) of broiler breeders 5 , 6 and 8 weeks after the trial commenced, according to the feed allowances in Phase 1 and 2

\begin{tabular}{|c|c|c|c|c|c|c|}
\hline \multirow{2}{*}{$\begin{array}{l}\text { Feed allowance } \\
\qquad(\mathrm{g} / \mathrm{d})\end{array}$} & \multicolumn{2}{|c|}{ Week 5} & \multicolumn{2}{|c|}{ Week 6} & \multicolumn{2}{|c|}{ Week 8} \\
\hline & $\begin{array}{c}\text { Fat pad } \\
\mathrm{g} / \mathrm{kg}\end{array}$ & $\begin{array}{l}\text { Body lipid } \\
\text { g/kg }\end{array}$ & $\begin{array}{l}\text { Fat pad } \\
\mathrm{g} / \mathrm{kg}\end{array}$ & $\begin{array}{c}\text { Body lipid } \\
\text { g/kg }\end{array}$ & $\begin{array}{c}\text { Fat pad } \\
\mathrm{g} / \mathrm{kg}\end{array}$ & $\begin{array}{c}\text { Body lipid } \\
\mathrm{g} / \mathrm{kg}\end{array}$ \\
\hline \multicolumn{7}{|l|}{ Phase 1} \\
\hline 160 & 18.0 & 159 & 16.1 & 152 & 14.5 & 126 \\
\hline 175 & 20.0 & 165 & 19.0 & 167 & 15.3 & 131 \\
\hline 190 & 19.0 & 162 & 14.3 & 143 & 17.1 & 138 \\
\hline 205 & 22.2 & 173 & 19.1 & 167 & 14.8 & 128 \\
\hline SEM & 0.86 & 2.87 & 0.69 & 3.33 & 0.64 & 3.00 \\
\hline \multicolumn{7}{|l|}{ Phase 2} \\
\hline 80 & 19.3 & 163 & 15.0 & 147 & 12.8 & 119 \\
\hline 100 & 19.7 & 164 & 16.7 & 155 & 14.6 & 127 \\
\hline 120 & 20.5 & 167 & 19.7 & 170 & 19.0 & 147 \\
\hline SEM & 0.87 & 2.91 & 0.70 & 3.38 & 0.61 & 2.82 \\
\hline
\end{tabular}

SEM: standard error of mean.

Table 8 The relationship between carcass lipid $(\mathrm{g} / \mathrm{kg})$ and abdominal fat content $(\mathrm{g} / \mathrm{kg})$ of the carcasses analysed 5, 6 and 8 weeks after the start of the trial

\begin{tabular}{ccrccc}
\hline Age (week) & Constant term & SE & Linear coefficient & SE & $\mathrm{R}^{2}(\%)$ \\
\hline 42 & $103^{* * *}$ & 11.8 & $3.3^{* * * *}$ & 0.417 & 87.3 \\
43 & $76.5^{* * *}$ & 8.1 & $4.9^{* * *}$ & 0.383 & 94.8 \\
45 & $63.3^{* * *}$ & 7.5 & $4.6^{* * *}$ & 0.325 & 95.6 \\
\hline
\end{tabular}

*** $P<0.001$.

SE: standard error.

these methods of analysis require the whole bird to be minced thereby incurring considerable expense when the carcass composition of so many broiler breeders is required. Consequently we used yet another, less destructive method of predicting carcass lipid, namely, to dissect out and weigh the abdominal fat pad only, which we have also shown to be an accurate predictor of the body lipid content of broiler breeders.

All birds lost weight during Phase 2, reflecting the low energy intake in relation to requirement during this period. The amount of weight lost appeared to be unrelated to the food allocated during Phase 1, but was least with the highest allocation in Phase 2. It can be assumed that the loss in weight was predominantly lipid, for the reasons given above.

Hens fed either 100 or $120 \mathrm{~g} / \mathrm{d}$ in Phase 2 were able to maintain their performance over the four weeks of this phase, with mean rates of lay of 57 and 66 eggs/100 birds per d, respectively, over the final two weeks of the trial. Birds from the same flock were kept on the floor, and on $160 \mathrm{~g} / \mathrm{bird} \mathrm{d}$ of a commercial broiler breeder feed (11.9 MJ ME/kg, $159 \mathrm{~g}$ protein $/ \mathrm{kg}$ ) their rate of lay over this period was $63 \mathrm{eggs} / 100$ birds per $\mathrm{d}$, thus confirming that the performance of birds on these two feed allocations was acceptable. Rate of lay of birds fed $80 \mathrm{~g} / \mathrm{d}$ was directly related to daily energy intake in Phase 1, and clearly demonstrated that egg production could be sustained for a short period of time if lipid reserves were available, and the daily food allocation provided sufficient nutrients (other than energy).

Egg weight was not affected by any of the feed allocations until the third week of Phase 2 . At this stage, eggs laid by hens given $80 \mathrm{~g} / \mathrm{d}(805 \mathrm{~kJ}$ AME/d, $16.8 \mathrm{~g} \mathrm{CP} / \mathrm{d})$ reduced in size. Protein intake would 
have been marginally limiting for reproductive performance at this daily feed allowance, but this would also have been due to a shortage of energy per se. As suggested by Miller \& Payne (1961) and Pearson \& Herron (1980), energy requirements might be satisfied preferentially to protein requirements, reflecting an increase in the utilisation of protein as an energy source. This would result in a decrease in protein available for egg formation.

Table 9 Rate of change in body lipid content ( $\mathrm{g} / \mathrm{kg}$ body weight /d) of broiler breeders over the last four weeks of the experiment according to the feed allowance in Phases 1 and 2

\begin{tabular}{|c|c|c|c|}
\hline \multicolumn{2}{|c|}{ Food allocation (g/d) } & \multicolumn{2}{|c|}{$\begin{array}{l}\text { Change in body lipid } \\
\text { (g/kg body weight } d)\end{array}$} \\
\hline Phase 1 & Phase 2 & Linear term & $\mathrm{SE}$ \\
\hline 160 & 80 & $-2.1 * * *$ & 0.57 \\
\hline 160 & 100 & $-1.7 * *$ & 0.57 \\
\hline 160 & 120 & -1.0 & \\
\hline 175 & 80 & $-2.2 * *$ & 0.73 \\
\hline 175 & 100 & $-2.0 * * *$ & 0.54 \\
\hline 175 & 120 & -1.3 & \\
\hline 190 & 80 & $-1.9 *$ & 0.69 \\
\hline 190 & 100 & -0.8 & \\
\hline 190 & 120 & -0.3 & \\
\hline 205 & 80 & $-2.1 * *$ & 0.66 \\
\hline 205 & 100 & $-2.9 * * *$ & 0.60 \\
\hline 205 & 120 & $-1.8^{*}$ & 0.79 \\
\hline
\end{tabular}

This trial was not designed to determine the energy requirements of broiler breeder hens, but rather to ascertain whether, for a short period of time, such hens could maintain their egg production at an energy intake that is lower than recommended. To measure this, the changes in rate of lay during Phase 2 of the trial were therefore of greater importance than were the changes in body lipid content, so the relative uncertainty of the magnitude of these latter changes resulting from the use of GE and abdominal fat as measures of the body lipid content is of lesser importance. However, these changes nevertheless reflect a reduction in body lipid content in all treatments during Phase 2. Energy intake on each of the three treatments in Phase 2 of this trial was only 805,1006 and $1208 \mathrm{~kJ} /$ bird d, respectively, whereas recommended energy intakes range from 1730 (Pearson \& Herron, 1981) through 1840 and 1955 (Cobb, 2005) to $2000 \mathrm{~kJ}$ ME/bird d (Bowmaker $\&$ Gous, 1991). The birds in this study clearly obtained the balance of energy required for egg production from body lipid reserves, the birds receiving 80, 100 and $120 \mathrm{~g} / \mathrm{d}$ in Phase 2 losing body weight at a rate of $2.3,1.9$ and $1.1 \mathrm{~g} / \mathrm{d}$ respectively.

As was expected, the use of body lipid reserves increased with decreasing feed allocations in Phase 2. Assuming that $8.4 \mathrm{~kJ}$ ME is required per g egg output (Emmans, 1974), an output of $48 \mathrm{~g} / \mathrm{d}$ would require $403 \mathrm{~kJ} \mathrm{ME} / \mathrm{d}$. The difference in intake between birds given $80 \mathrm{~g}$ and those given $100 \mathrm{~g} / \mathrm{d}$ is $201 \mathrm{~kJ} \mathrm{ME}$, half the amount required for $48 \mathrm{~g}$ egg output/d, and the difference between the intakes of 80 and $120 \mathrm{~g}$ is $403 \mathrm{~kJ}$, the equivalent of one egg. Consequently, the additional energy provided to birds on $120 \mathrm{~g} / \mathrm{d}$ was sufficient to enable them to lay at the given rate throughout the second phase of the trial compared with the birds given 80 $\mathrm{g} / \mathrm{d}$. It is assumed that the energy required for maintenance was essentially the same for hens on all treatments, as this is related to the body protein content and not the energy content of the body, and it appeared that body protein content remained constant in all treatments. 
Broiler breeder hens would be unable to make use of all their lipid reserves to enable them to continue to lay when food intake is severely restricted because a minimum amount of body lipid is needed to maintain the birds (Wellock et al., 2003). This trial suggests that the minimum lipid content would be around $110 \mathrm{~g} / \mathrm{kg}$ body weight, given that the amount in the hens fed $80 \mathrm{~g} / \mathrm{d}$ was close to this concentration. This concentration of lipid in the body could be used as the minimum lipid content when modelling energy utilisation of broiler breeders after sexual maturity.

\section{Conclusion}

Broiler breeder hens can maintain their egg production for a number of days at an energy intake that is lower than is required for maintenance and egg production by utilising body lipid reserves as an energy source.

\section{Acknowledgements}

The authors wish to thank the staff at the poultry section of the University Research farm, D. Davies, M. Hundley and S. Opperman for their technical assistance. They also acknowledge the generous financial contribution made by the Protein Research Foundation, the National Research Foundation and CobbVantress Inc., USA towards the running of these trials, and the supply of the day-old parent-stock.

\section{References}

AOAC, 1975. Official methods of analysis ( $10^{\text {th }}$ ed.). Association of Official Analytical Chemists, Inc., Arlington, Washington, USA.

Bowmaker, J.E. \& Gous, R.M., 1991. The response of broiler breeder hens to dietary lysine and methionine. Br. Poult. Sci. 32, 1069-1088.

Dennison, C. \& Gous, R.M., 1980. Amino acid concentrations in some South African feed ingredients. S. Afr. J. Anim. Sci. 10, 9-18.

Emmans, G.C., 1974. The effect of temperature on performance of laying hens. In: Energy Requirements of Poultry. Eds Morris, T.R. \& Freeman, B.M., Proceedings of Poultry Science, Edinburgh. pp. 79-90.

Genstat, 1997. Genstat 5 (Release 5.1) Committee of the Statistic Department, Rothamsted Experimental Station. Oxford, Clarendon Press.

Gous, R.M., Emmans, G.C. \& Fisher, C., 1992. The response of broilers to feeds differing in protein content following a period of fattening. Thirteenth annual meeting of the Southern Poultry Science Society, Atlanta, Georgia.

Gous, R.M., Emmans, G.C. \& Fisher, C., 2012. The performance of broilers on a feed depends on the feed protein content given previously. S. Afr. J. Anim. Sci. 42, 63-73.

McDaniel, G.R., Brake, J. \& Eckman, M.K., 1981. Factors affecting broiler breeder performance. 4. The interrelationship of some reproductive traits. Poult. Sci. 60, 1792-1797.

McNab, J.M. \& Blair, J.C., 1988. Modified assay for true and apparent metabolisable energy based on tube feeding. Br. Poult. Sci. 29, 697-707.

Miller, D.S. \& Payne, P.R., 1961. Problems in the prediction of protein values of diets: caloric restriction. J. Nutr. 75, 225-330.

Pearson, R.A. \& Herron, K.M., 1980. Feeding standards during lay and reproductive performance of broiler breeders. Br. Poult. Sci. 21, 171-181.

Pearson, R.A. \& Herron, K.M., 1981. Effects of energy and protein allowance during lay on the reproductive performance of broiler breeder hens. Br. Poult. Sci. 22, 227-239.

Pearson, R.A. \& Herron, K.M., 1982. Relationship between energy and protein intakes and laying characteristics in individually caged broiler breeder hens. Br. Poult. Sci. 23, 145-159.

Wellock, I.J., Emmans, G.C. \& Kyriazakis, I., 2003. Modelling the effects of thermal environment and dietary composition on pg performance: modellogic and concept. Anim. Sci. 77, 255-266.

Wilson, H.R. \& Harms, R.H., 1986. Performance of broiler breeders as affected by body weight during the breeding season. Poult. Sci. 74: Supplement 1. p. 12 (abstract). 